\title{
PENGEMBANGAN MODUL FISIKA BERBASIS DISCOVERY LEARNING (DL) PADA POKOK BAHASAN KESEIMBANGAN DAN DINAMIKA ROTASI
}

\author{
Nabillah Unanti ${ }^{1}$, Endang Lovisia ${ }^{2}$ \\ nabillah.unanti@yahoo.com \\ ${ }^{1,2}$ Program Studi Pendidikan Fisika STKIP PGRI Lubuklinggau, Sumatera Selatan, Indonesia
}

Received: 3 Desember $2021 \quad$ Revised: 4 Desember $2021 \quad$ Accepted: 18 Desember 2021

\begin{abstract}
This study aims to develop a physics based discovery learning $(D L)$ module on the subject of balance and dynamics of rotation which is valid and practical. The problems in this research are 1) how to develop a physics module based on discovery learning $(D L)$ on the subject of balance and rotation dynamics of student in class XI of SMA Negeri 2 reference Muara Beliti. 2) how are the characteristics of the physics module based on discovery learning $(D L)$ to fulfill the goals of validity and practicality on the subject of balance and rotation dynamics of student in class XI SMA Negeri 2 reference muara beliti. The subject in this study were class XI MIPA 3 SMA Negeri 2 reference muara beliti which consisted of 9 students who were taken by purposive sampling technique. The develop of this research uses a four-D model consisting of define, design, develop and dessimination. The data was collected by using a student response questionnaire technique. And validation consists of 3 expert validations, material validation with an assessment of 37 in the good category, language validation with an assessment of 18 in the good category, and media validation with an assessment of 27 in the good category. Validation carried out to get results with an assessment of 82 in the good category. Students responses to the physics module based on discovery learning with an assessment of 33 in the very good category. So it can be said that the physics module based on discovery learning thet has been developed is valid and pratical
\end{abstract}

\begin{abstract}
Abstrak: Penelitian ini bertujuan untuk mengembangan Modul Fisika Berbasis discovery learning (DL) pada pokok bahasan Kesetimbangan dan Dinamika Rotasi yang valid, dan praktis. Masalah dalam penelitian ini adalah 1)Bagaimana Mengembangkan Modul Fisika Berbasis Discovery Learning (DL) Pada Pokok Bahasan Keseimbangan dan Dinamika Rotasi Siswa di Kelas XI SMA Negeri 2 Rujukan Muara Beliti. 2)Bagaimana Karakteristik Modul Fisika Berbasis Discovery Learning (DL) Untuk Memenuhi Sasaran Kevalidan dan Kepraktisan Pada Pokok Bahasan Keseimbangan dan Dinamika Rotasi Siswa di Kelas XI SMA Negeri 2 Rujukan Muara Beliti. Subjek dalam penelitian ini adalah kelas XI MIPA 3 SMA Negeri 2 Rujukan Muara Beliti yang terdiri dari 9 siswa yang diambil dengan teknik purposive sampling. Pengembangan penelitian ini menggunakan model Four-D yang terdiri dari Define, Design, Develop dan Dessimination. Pengumpulan data dilakukan dengan teknik angket respon siswa. Dan validasi terdiri dari 3 validasi ahli, validasi materi dengan penilaian 37 dalam kategori baik, validasi bahasa dengan penilaian 18 dalam kategori baik, dan validasi media dengan penilaian 27 dalam kategori baik. Validasi yang dilakukan mendapatkan hasil dengan penilaian 82 dalam kategori baik Respon siswa terhadap modul fisika berbasis Discovery Learning dengan penilaian 33 dalam kategori sangat baik. Sehingga dapat dikatakan bahwa Modul fisika berbasis Discovery Learning yang dikembangkan telah valid,dan praktis.
\end{abstract}

Kata kunci : Pengembangan Modul, berbasis discovery learning.

\section{PENDAHULUAN}

Sarana dan prasarana merupakan salah satu bagian terpenting dalam meningkatkan mutu pendidikan. Sarana dan prasana dapat digunakan untuk menunjang proses pembelajaran agar 
dapat berjalan lancar sehingga peserta didik dapat optimal dalam proses pembelajaran. Salah satu sarana prasana yang dapat menunjang proses pembelajaran yaitu bahan ajar. Salah satu penunjang pembelajaran yang digunakan pada saat proses pembelajaran dengan menggunakan media pembelajaran, media yang dapat digunakan yaitu modul.

Mengingat pentingnya peranan modul untuk meningkatkan kualitas proses pembelajaran di SMA, maka guru sebagai orang yang paling bertanggung jawab terhadap keberhasilan proses pembelajaran, dituntut untuk dapat memahami pengertian, karakteristik, prinsip, ketentuan dan prosedur pengembangan modul. Pembelajaran dengan menggunakan modul tidak hanya berfokus pada guru tetapi siswa dapat melakukan secara mandiri. Penggunaan modul juga tidak bergantung lagi pada media pembelajaran lain atau tidak harus digunakan bersama-sama dengan media yang lain sehingga lebih efisien.

Modul merupakan komponen yang memiliki peran penting dalam proses pembelajaran. Ketersediaan modul dapat membantu siswa dalam memperoleh informasi tentang materi pembelajaran. Namun demikian, dalam pengembangan modul perlu disesuaikan dengan kebutuhan siswa. Pentingnya ketersediaan modul yang dikembangkan dengan memanfaatkan hasil-hasil penelitian pendidikan karena materi yang akan disajikan akan menghubungkan keterkaitan antara fakta yang diperoleh dari pengumpulan data, konsep dari kajian teori, prosedur dan prinsip yang terkandung dalam materi pembelajaran (Peniati, E, 2012). Lebih lanjut Daryanto (2013) mengemukakan bahwa modul itu merupakan salah satu bentuk dari bahan ajar yang dibuat secara utuh dan sistematis yang memuat seperangkat pengalaman belajar yang telah terencana dan didesain agar dapat membantu peserta didik menguasai tujuan belajar yang lebih spesifik.

Proses pembelajaran Ilmu Pengetahuan Alam (IPA) termasuk fisika mestinya menekankan pada pemberian pengalaman langsung kepada siswa sehingga siswa memperoleh pemahaman mendalamtentang alam sekitar dan prospek pengembangan lebih lanjut dapat menerapkannya di dalam kehidupan kehidupan sehari-hari (Miswati, M., Amin, A., \& Lovisia, E, 2020). Pembelajaran IPA di sekolah seharusnya melibatkan aspek sikap, proses, produk, dan aplikasi, sehingga siswa dapat mengalamiproses pembelajaran secara utuh, memahami fenomena alam melalui kegiatan pemecahan masalah, metode ilmiah, dan meniru kerja ilmuan dalam menemukan fakta baru (Ariani, T., \& Suanti, W, 2016).

Berdasarkan hasil observasi yang telah dilakukan di SMA Negeri 2 Rujukan Muara Beliti kelas XI semester ganjil pada tanggal 22 Juli 2020 dan hasil wawancara dengan guru dan siswa yang telah didapatkan di SMA Negeri 2 Rujukan Muara Beliti sudah menerapkan 
kurikulum 2013, namun belum sempurna dan hasilnya kurang baik karena kurangnya minat baca dan minat siswa mencari sumber informasi dan siswa masih berpusat kepada guru dalam proses belajar mengajar atau pembelajaran konvesional. Model pembelajaran Discovery Learning telah diterapkan di SMA Negeri 2 Rujukan Muara Beliti untuk pembelajaran fisika namun model tersebut hanya digunakan untuk beberapa materi saja. Pada saat dilakukannya wawancara dengan guru, hanya beberapa siswa saja yang menyukai pelajaran fisika, karena faktor kesulitan buku yang diterima siswa. Buku ajar yang digunakan guru ada buku guru , buku siswa, dan modul berbasis Discovery Learning tapi tidak semua materi hanya beberapa materi saja guru di SMA Negeri 2 Rujukan Muara Beliti memiliki modul berbasis Discovery Learning.

Penggunaan modul fisika berbasis discovery learning mampu membuat siswa akan lebih tertarik dan bisa mengerti materi dengan mudah karena semua permasalahan yang dihadapi oleh siswa semuanya bisa diatasi sendiri oleh siswa. Dengan menemukan sendiri jawaban dari permasalahan siswa menjadi lebih mudah dalam mengingat pelajaran dan lebih semangat dalam membangun pengetahuan yang lebih lagi. Penerapan model pembelajaran discovery learning pada pembelajaran sains saat ini sangat dianjurkan untuk melibatkan siswa dalam proses belajar secara aktif, sehingga apa yang dihadapi siswa ketika belajar tidak lagi menjadi subjek yang pasif yang hanya duduk, diam, ribut, mengantuk, hanya fokus mendengarkan saja, serta gagal dalam menyelesaikan soal-soal yang memang sulit bagi mereka dan siswa akan lebih mampu lagi dalam mengasah pemahamannya (Apriyani, N., Ariani, T., \& Arini, W, 2020).

Berdasarkan hasil wawancara yang telah dilakukan ke-9 peserta didik di kelas XI IPA 3 dengan tingkat kemampuan tinggi, sedang, dan rendah. Untuk siswa yang kemampuan rendah mereka mengatakan bahwa fisika pelajaran yang cukup sulit dan tidak diminati oleh mereka. Namun untuk siswa yang berkemampuan sedang mereka sedikit menyukai pelajaran fisika dan untuk siswa yang memiliki kemampuan tinggi mengatakan bahwa fisika pelajaran yang asyik dan menantang.

Setelah dilakukan wawancara peserta didik mengatakan masih kesulitan dalam menyelesaikan soal fisika yang diberikan guru pelajaran fisika. Pada saat dilakukannya wawancara dengan guru fisika, guru tersebut bercerita bahwa peserta didik belum mampu memberikan hasil jawabannya sendiri pada saat diberikannya soal setelah pembelajaran berlangsung kebanyakan masih melalui hafalan yang telah didengar sebelumnya sehingga peserta didik belum mamapu menyelesaikan soal analisis. Padahal sekarang sudah diterapkan 
kurikulum 2013 dimana kurikulum ini menuntut pembelajaran secara saintifik (scientific) pembelajaran secara ilmiah bukan pembelajaran konvesional supaya peserta didik mampu lebih mandiri dan mampu berpikir kreatif.

Serta berdasarkan hasil tes diagnosis yang peneliti lakukan dengan 9 Berdasarkan latar belakang yang telah dikemukakan diatas, perlu dilakukan pengembangan sumber belajar melalui modul yang berbasis Discovery Learning (DL) yang dirancang secara menarik dan lebih mudah dipahami. Diharapkan dapat membantu guru dan membuat kegiatan pembelajaran lebih efektif dan efisien sehingga peneliti tertarik melakukan penelitian. Adapun rumusan masalah Mengembangkan Modul Fisika Berbasis Discovery Learning (DL) pada Pokok Bahasan Keseimbangan dan Gerak Rotasi Siswa di kelas XI SMA Negeri 2 Rujukan Muara Beliti, dan karakteristik modul fisika berbasis discovery learning (DL) melalui sasaran kevalidan dan kepraktisan.

Tujuan dalam penelitian ini yaitu, 1. Mengembangkan modul fisika berbasis discovery learning (DL) pada pokok bahasan Keseimbangan Dan Dinamika Rotasi Siswa kelas XI SMA Negeri 2 Rujukan Muara Beliti. 2. Karakteristik modul fisika berbasis discovery learning (DL) untuk memenuhi Sasaran Kevalidan Dan Kepraktisan Pada Pokok Bahasan Keseimbangan Dan Dinamika Rotasi Siswa Kelas XI SMA Negeri 2 Rujukan Muara Beliti.

\section{METODOLOGI PENELITIAN}

Jenis penelitian yang digunakan dalam penelitian ini adalah penelitian dan pengembangan (research and development). Menurut Sugiyono, R\&D adalah metode penelitian yang digunakan untuk menghasilkan produk tertentu dan menguji keefektifan produk (Sugiyono, 2012). Model pengembangan yang digunakan yaitu Four-D merupakan sebuah singkatan dari beberapa kata yaitu define, design, development, dan dessimination. Adapun bagian langkah-langkah model pengembangan Four-D milik Thiagarajan dapat dilihat seperti gambar 1 dibawah ini: 


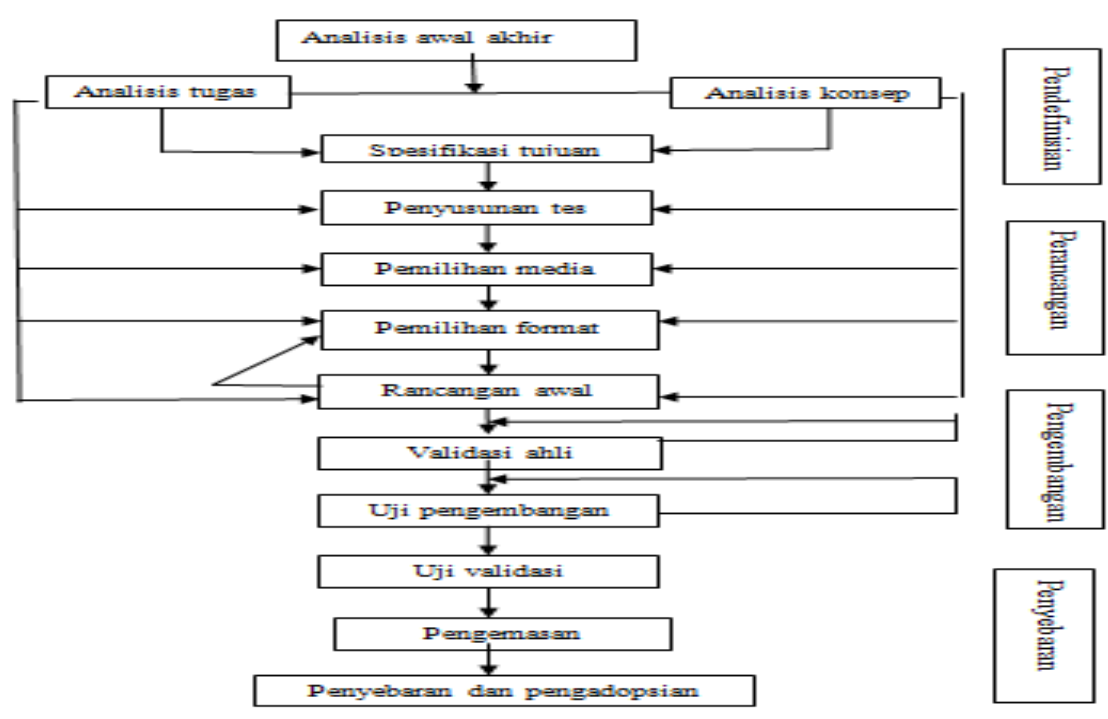

Gambar 2.3 Model Pengembangan Perangkat Pembelajaran Four-D (Trianto, 20110

Pada modul berbasis Discovery Learning (DL) ini peserta didik dapat lebih aktif dan mandiri dalam pemecahan suatu masalah. Hal ini sejalan dengan kurikulum 2013 yang diterapkan saat ini dimana pada proses pembelajarannya lebih mengedepankan pada keaktifan peserta didik di kelas. Sejalan dengan penjelasan diatas, pendekatan Discovery Learning (DL) sendiri memiliki 6 langkah pada kegiatan pembelajarannya antara lain: stimulasi (stimulation), identifikasi masalah (problem statment), pengumpulan data (data collection), pengolahan data (data processing), pembuktian (verification), menarik kesimpulan (generalization).

Dimana tahap stimulasi (stimulation) adalah tahap yang menggunakan teknik bertanya yaitu dengan mengajukan pertanyaan-pertanyaan yang dapat menghadapkan siswa pada kondisi internal yang mendorong eksplorasi. Kemudian identifikasi masalah (problem statment) adalah guru memberi kesempatan kepada siswa untuk mengidentifikasi sebanyak mungkin agenda-agenda masalah yang relevan dengan bahan pelajaran, kemudian salah satunya dipilih dan dirumuskan dalam bentuk hipotesis (jawaban sementara atas pernyataan masalah). Pada tahap pengumpulan data (data collection) tahapan ini siswa belajar secara aktif untuk menemukan sesuatu yang berhubungan dengan permasalahan yang dihadapi. Untuk tahapan pengolahan data (data processing) Tahapan pada data merupakan kegiatan mengolah data dan informasi yang telah diperoleh para siswa baik melalui wawancara, observasi, dan sebagainya, semuanya diolah, diacak, diklarifikasi, ditabulasi bahkan bila perlu diperhitungkan. Pada tahap pembuktian (verification) Pada tahap ini siswa melakukan 
pemeriksaan secara cermat untuk membuktikan benar atau tidaknya hipotesis yang diterapkan dengan temuan alternatif. Dan yang terakhir tahapan menyimpulkan (generalization) adalah proses menarik kesimpulan yang dapat dijadikan prinsip umum dan berlaku untuk semua kejadian atau masalah yang sama.

Modul yang akan dikembangkan menggunakan konsep model pengembangan Four-D milik Thiagarajan, Semmel, dan Semmel dimana menggunakan 3 tahapan dari 4 tahapan yang ada. Modul tersebut nantinya akan divalidasi oleh 3 ahli, yaitu ahli materi, media dan bahasa. Setelah proses validasi selesai, langkah selanjutnya yaitu melakukan revisi modul sesuai saran dari validator mengenai kekurangan dari modul tersebut. Setelah revisi produk selesai dilakukan, maka langkah selanjutnya yaitu melakukan tahapan uji coba. Dalam tahapan uji coba ini hanya dilakukan langkah small group atau kelompok kecil. Uji coba kelompok kecil dilakukan dikelas XI IPA dengan pengambilan sampelnya yaitu menggunakan teknik Simple Random Sampling. Uji coba yang akan dilakukan nantinya menggunakan angket respon dengan 10 indikator pernyataan yang harus diberikan penilaian sehingga peneliti dapat menarik kesimpulan apakah modul tersebut termasuk dalam kategori praktis atau masih perlu perbaikan lagi. Angket yang digunakan nantinya menggunakan Skala Likert Tipe-4.

Uji coba kelompok kecil/ kelompok terbatas Uji coba pemakaian modul selanjutnya dilakukan di SMA Negeri 2 Rujukan Muara Beliti di kelas XI dengan jumlah 9 siswa. Dimana siswa yang dipilih merupakan perwakilan dari 3 siswa yang memiliki kemampuan tinggi, 3 siswa yang memiliki kemampuan sedang, dan 3 siswa yang memiliki kemampuan rendah serta pengemasannyapun dilakukan berdasarkan hasil masukan dan saran dari siswa dan pengamat di SMA Negeri 2 Rujukan Muara Beliti. Uji coba terbatas dilakukan untuk melihat kepraktisan modul fisika yang dikembangkan. Sampel diambil dengan menggunakan teknik purposive sampling. Dengan diberikan produk serta angket yang berisi poin-poin tentang produk yang dikembangkan oleh si peneliti. Yang bertugas memperbaiki desain modul tersebut adalah peneliti yang ingin mengembangkan modul tersebut. Maka yang mulamula berupa skor, diubah menjadi data kualitatif (Data interval) dengan skala lima. Adapun acuan pengubahan skor menjadi skala lima tersebut menurut Sukardjo (2008) sebagai berikut

Tabel 1. Kriteria peniliaian kevalidan oleh ahli

No Rentang Skor Nilai Kategori




\begin{tabular}{lcll}
\hline 1. & $X>\bar{x}+1,80 S b i$ & A & Sangat Baik \\
2. & $\bar{x}+0,60 S b i<X \leq \bar{x}+1,80 S b i$ & B & Baik \\
3. & $\bar{x}-0,60 S b i<X \leq \bar{x}+0,60 S b i$ & C & Cukup Baik \\
4. & $\bar{x}-1,80 S b i<X \leq \bar{x}+0,60 S b i$ & D & Kurang Baik \\
5. & $X \leq \bar{x}+1,80 S b i$ & E & Sangat Kurang Baik \\
\hline
\end{tabular}

Uji coba kelompok kecil/ kelompok terbatas Uji coba pemakaian modul selanjutnya dilakukan di SMA Negeri 2 Rujukan Muara Beliti di kelas XI dengan jumlah 9 siswa. Dimana siswa yang dipilih merupakan perwakilan dari 3 siswa yang memiliki kemampuan tinggi, 3 siswa yang memiliki kemampuan sedang, dan 3 siswa yang memiliki kemampuan rendah serta pengemasannyapun dilakukan berdasarkan hasil masukan dan saran dari siswa dan pengamat di SMA Negeri 2 Rujukan Muara Beliti. Uji coba terbatas dilakukan untuk melihat kepraktisan modul fisika yang dikembangkan. Sampel diambil dengan menggunakan teknik purposive sampling. Setelah pengujian terhadap produk berhasil, dan mungkin ada revisi yang tidak terlalu penting, maka selanjutnya produk yang berupa sistem kerja baru tersebut diterapkan dalam kondisi nyata untuk lingkup yang luas. Dalam operasinya sistem kerja baru tersebut, tetap harus dinilai kekurangan atau hambatan yang muncul guna untuk perbaikan lebih lanjut.

\section{HASIL PENELITIAN}

\section{Modul draf I}

Pada modul darft I, peneliti merancang modul fisika berbis Discovery Learning dengan materi kesetimbangan dan dinamika rotasi yang belum divalidasi dan dinilai. Modul yang dikembangkan adalah yang paling awal dan masih sangat sederhana. Modul dikembangkan dengan menggunakan photoshop, photoscape dan ms word.

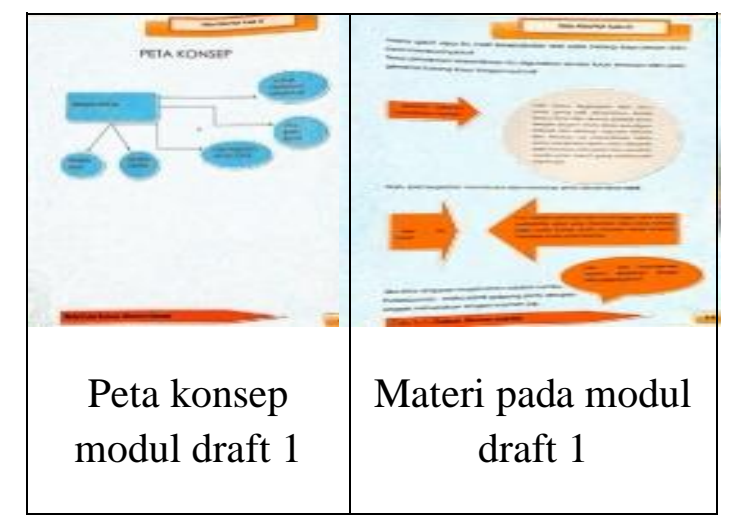




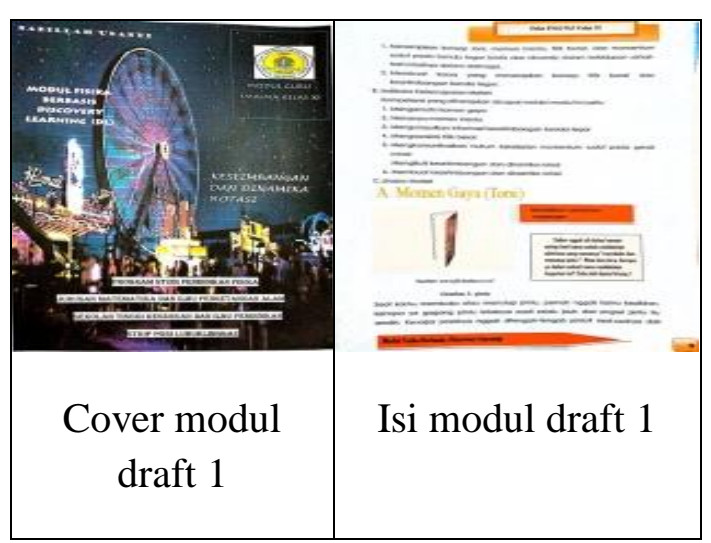

Gambar 2. Draf modul I

\section{Modul draf II}

Pada draft 2 ini dalam modul fisika berbasis discovery learning pada materi keseimbangan dan dinamika rotasi sudah melewati tahap draft 1 modul akan direvisi sesuai dengan saran dan komentar dari dosen pembimbing. Kemudian si peneliti melaukan tahap revisi dari hasil yang diberikan oleh dosen pembimbing.

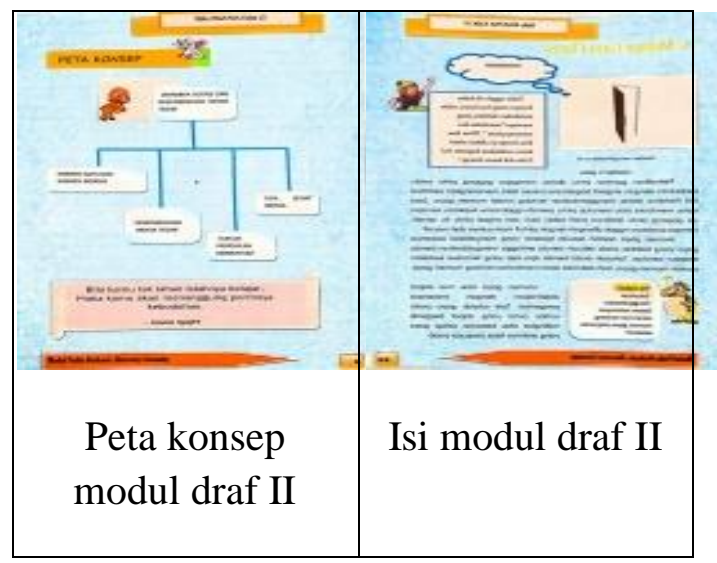

Gambar 3. Draf modul II

\section{Modul Final}

Setelah modul draft I dan draft 2 diberikan penilaian dan divalidasi maka modul siap untuk diuji cobakan dalam penelitian di SMA Negeri 2 Rujukan Muara Beliti. Modul final dapat dilihat pada gambar 4.

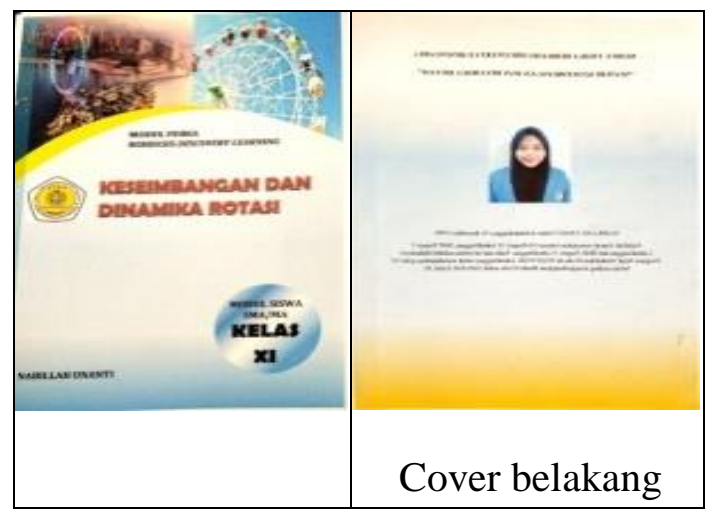

Puplished at https://ojs.stkippgri-lubuklinggau.ac.id/index.php/SJPIF 


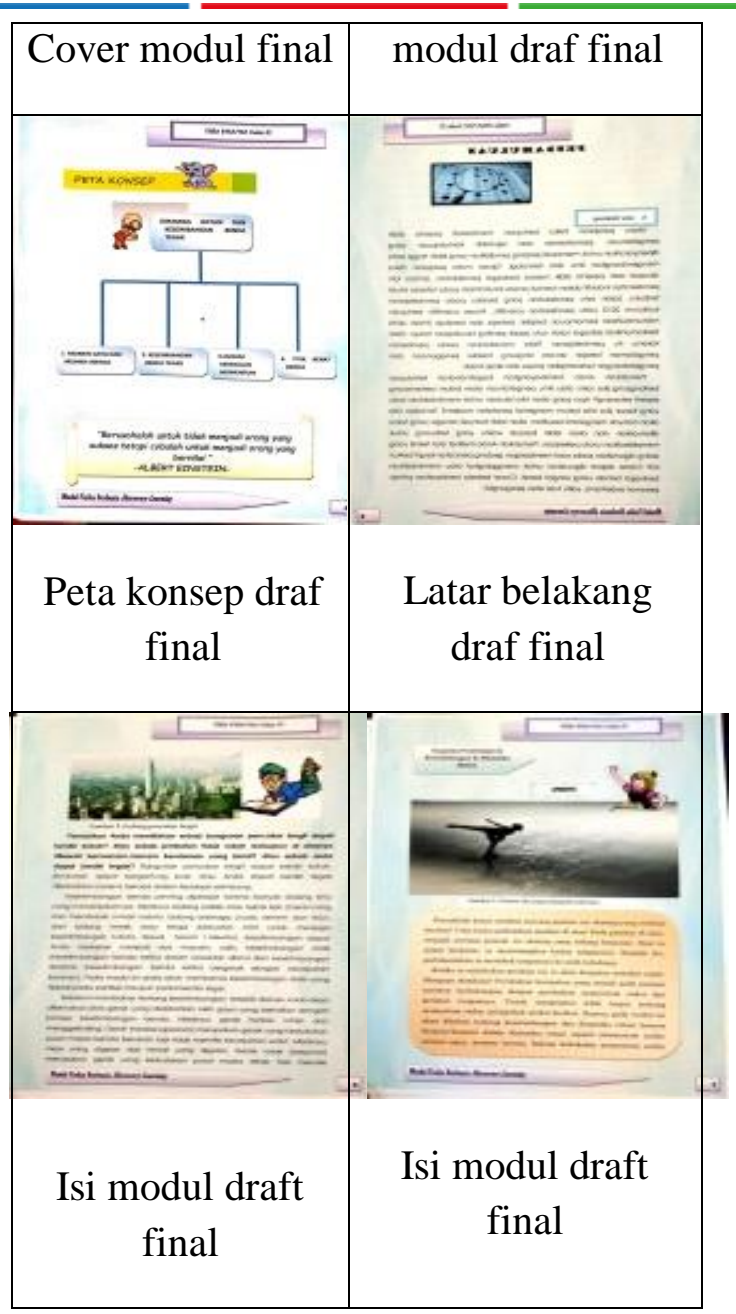

Gambar 4. Buku Ajar Final

Setelah melewati modul draft 1 dan 2 dengan melakukan bimbingan kepada dosen pembimbing tentang produk yang dikembangkan didapat hasil modul final. Modul final sudah sesuai dengan arahan, masukan, dan saran dari dosen pembimbing sebelum dilakukan validasi. Setelah modul final dicetak maka modul akan dilakukan pengecekan validasi dengan menggunakan 3 validator ahli yang dipilih oleh salah satu dosen fisika.

\section{Kevalidam Modul}

Kelayakan modul fisika berbasis discovery learning pada materi keseimbangan dan dinamika rotasi melalui tahap evaluasi ahli untuk melihat kevalidan modul yang divalidasi oleh materi ahli, desain dan bahasa sehingga modul tersebut baik digunakan ke peserta didik kemudian tahap kelayakan pada modul ini akan dilaksanakan uji coba kelompok terbatas. Kelayakan modul fisika berbasis discovery learning pada kelayakan modul secara teoritik terdiri dari ahli materi, desain dan bahasa sebagai berikut.

a. Evaluasi ahli 
Evaluasi ahli dilakukan untuk menyempurnakan modul fisika yang dikembangkan ada tiga aspek dari segi materi, media dan bahasa. Ketiga aspek ini dinilai oleh 3 orang validasi, 1 orang ahli materi guru fisika, 1 orang ahli media dari dosen , 1 orang ahli bahasa dari dosen. Instrumen yang digunakan adalah angket terbuka yang mana para ahli nantinya bisa memberikan komentar dan saran sesuai dengan apa yang ada dipikiran setiap validator. Setiap validator diberikan angket terbuka guna untuk melihat produk yang sedang dikembangkan oleh si peneliti.

1. Ahli materi

Evaluasi ahli materi dilakukan untuk mengetahui kelayakan cakupan materi, akurasi materi, dan kediscovery-an yang terdiri dari 12 butir pertanyaan. Evaluasi menggunakan angket terbuka, sehingga validator bisa memberikan kritik, saran, dan masukan. Hasil validasi erdiri dari 3 aspek indikator, yaitu (a) cakupan materi, (b) akurasi materi, (c) kediscovery-an. Setelah didapat hasil dari validator materi maka si peneliti melakukan revisi atau perbaikan sesuai dengan saran, komentar, dan masukan yang terdapat di dalam angket yang sudah diberikan kepada validator materi tersebut.

Berikut ini tabel penilaian oleh pakar ahli baik dari salah satu guru Fisika Dalam hal ini validasi ahli materi dengan salah satu guru Fisika dapat dilihat pada table 2 dibawah ini:

Table 2. Hasil validasi ahli materi

\begin{tabular}{cccc}
\hline No & Rentang skor & Nilai & Kategori \\
\hline 1 & $\mathrm{X}>40,8$ & $\mathrm{~A}$ & Sangat baik \\
2 & $33,6<\mathrm{X} \leq 40,8$ & $\mathrm{~B}$ & Baik \\
3 & $26,4<\mathrm{X} \leq 33,6$ & $\mathrm{C}$ & Cukup baik \\
4 & $19,2<\mathrm{X} \leq 26,4$ & $\mathrm{D}$ & Kurang baik \\
5 & $\mathrm{X} \leq 19,2$ & $\mathrm{E}$ & Sangat kurang baik
\end{tabular}

Hasil tanggapan ahli pada komponen kelayakan materi termasuk dalam kategori valid yaitu dengan penilaian 37. Jadi, persentase keseluruhan dari validasi materi adalah 37 sehingga komponen kelayakan materi termasuk dalam kategori baik. Hasil yang didapat bahwa modul fisika berbasis discovery learning pada modul fisika sudah bagus dan menarik serta sesuai dengan kompetensi dasar dan indikator pencapaian kompetensi karena modul fisika berbasis discovery learning ini bisa diterapkan di sekolah sehingga peserta didik mengetahui hubungan antara teori dengan kehidupan sehari-hari.

2. Ahli Bahasa

Modul fisika yang dikembangkan diharapkan memiliki tingkat keterbacaan yang baik, sehingga dapat meningkatkan hasil belajar siswa dan ketertarikan dalam membaca modul Puplished at https://ojs.stkippgri-lubuklinggau.ac.id/index.php/SJPIF 
fiska berbasis discovery learning diambil salah satu dosen bahasa indonesia. Pada segi bahasa terdapat 6 aspek dan angket yang dipakai yaitu angket terbuka yang diberikan pada ahli bahasa digunakan untuk mendapatkan evaluasi terhadap komponen kebahasaan yang terdiri dari enam pertanyaan yang terdiri dari (a) ketetapa struktur kalimat dan kebakuan istilah, (b) keterbacaan pesan (isi), (c) kemampuan memotivasi pesan atau informasi, (d) kesesuaian pengembangan intelektual peserta didik, (e) keterkaitan antar kalimat, antar paragraph dan antar konsep, (f) konsisten penggunaan istilah dan simbol.

Table 3. Hasil validasi ahli bahasa

\begin{tabular}{cccc}
\hline No & Rentang skor & Nilai & Kategori \\
\hline 1 & $\mathrm{X}>20,4$ & $\mathrm{~A}$ & Sangat baik \\
2 & $16,8<\mathrm{X} \leq 20,4$ & $\mathrm{~B}$ & Baik \\
3 & $13,2<\mathrm{X} \leq 16,8$ & $\mathrm{C}$ & Cukup baik \\
4 & $4,2<\mathrm{X} \leq 13,2$ & $\mathrm{D}$ & Kurang baik \\
5 & $\mathrm{X} \leq 4,2$ & $\mathrm{E}$ & Sangat kurang baik
\end{tabular}

Hasil tanggapan ahli pada komponen kelayakan modul fisika berbasis discovery learning dari segi validasi bahasa pada materi keseimbangan dan dinamika rotasi dalam kategori valid dengan penilaian 18. Jadi, persentase keseluruhan dari validasi bahasa termasuk kelayakan dalam kategori baik dengan persentase 18 .

3). Validasi media

Hasil validasi ahli media modul fisika berbasis discovery learning dilakukan pada sembilan butir pertanyaan dengan diberikan angket terbuka, pada sembilan indikator pertanyaan meliputi : (a) konsistensi sistematika sajian dalam kegiatan belajar, (b) contoh soal dalam setiap kegiatan belajar, (c) soal latihan pada akhir kegiatan belajar, (d) kunci jawaban dan soal latihan, (e) kesesuaian latar warna dan kualitas layout, (f) keseimbangan antara ilustrasi gambar dan tulisan, (g) terdapat pengantar, daftar pustaka, dan rangkuman, (h) kelengkapan penyajian seperti pendahuluan, isi, dan penutup. Validasi media dilakukan sama seperti validasi materi dan bahasa kepada validator yang sudah dipilih.

Table 4. Hasil validasi ahli media

\begin{tabular}{cccc}
\hline No & Rentang skor & Nilai & Kategori \\
\hline 1 & $\mathrm{X}>30,6$ & A & Sangat baik \\
2 & $25,2<\mathrm{X} \leq 30,6$ & B & Baik \\
3 & $19,8<X \leq 25,5$ & C & Cukup baik \\
4 & $14,4<X \leq 19,8$ & D & Kurang baik \\
5 & $X \leq 14,4$ & E & Sangat kurang baik \\
\hline
\end{tabular}


Hasil tanggapan ahli pada komponen kelayakan modul fisika berbasis discovery learning pada materi keseimbangan dan dinamika rotasi dalam kategori valid dengan penlaian 27. Jadi, persentase keseluruhan dari validasi media adalah 27. Sehingga komponen kelayakan termasuk kedalam kategori baik dengan persentase 27.

Berdasarkan penilaian dari ketiga orang ahli terdapat modul berbasis discovery learning yang sudah diurutkan diatas menunjukkan penilaian yang baik. Oleh karena itu modul fisika berbasis discovery learning dapat dikatakan valid dan dapat digunakan untuk tahap selanjutnya yaitu tahap uji coba kelompok kecil/ kelompok terbatas yang akan dilakukan di SMA Negeri 2 Rujukan Muara beliti. Namun sebelum digunakan produk yang dikembangkan harus di revisi terlebih dahulu sesuai dengan saran dan masukan yang diberikan oleh para ahli. Berikut hasil perhitungan rekapitulasi hasil keseluruhan dari tiga ahli dapat dilihat pada tabel berikut ini

Table 5. rekapitulasi hasil keseluruhan dari tiga ahli

\begin{tabular}{cccc}
\hline No & Rentang skor & Nilai & Kategori \\
\hline 1 & $\mathrm{X}>91,8$ & A & Sangat baik \\
2 & $75,6<\mathrm{X} \leq 91,8$ & B & Baik \\
3 & $59,4<X \leq 75,6$ & C & Cukup baik \\
4 & $43,2<X \leq 59,4$ & D & Kurang baik \\
5 & $\mathrm{X} \leq 43,2$ & E & Sangat kurang baik \\
\hline
\end{tabular}

\section{Kepraktisan modul}

Dalam modul fisika berbasis discovery learnig pada materi keseimbangan dan dinamika rotasi pada kelayakan modul fisika terdiri dari pelaksanaan uji coba kelompok kecil atau kelompok terbatas dilakukan di SMA Negeri 2 Rujukan Muara Beliti dengan menggunakan 9 sampel dimana 9 peserta didik ini memiliki kemampuan yang berbeda-beda dengan tingkatan tinggi, sedang dan rendah. Intrumen untuk mengukur kepraktisan modul menggunakan angket respon

a. Pelaksanaan uji kelompok kecil/ kelompok terbatas

Uji kelompok kecil dilaksanakan dengan memberikan angket yang terdiri dari 10 butir pertanyaan kepada sembilan orang siswa yang diambil secara purposive sampling dari kelas XI MIPA 3. Angket ini bersifat angket terbuka dengan menggunakan skala likert mempunyai gradasi dari sangat setuju sampai sangat tidak setuju yang dapat dikategorikan sebagai berikut. Sangat setuju (SS), setuju (S), tidak setuju (TS), sangat tidak setuju (STS). Berikut ini cuplikan tentang respon siswa uji coba kelompok kecil terhadap modul fisika berbasis discovery learning materi keseimbangan dan dinamika rotasi sebagai berikut. Modul fisika Puplished at https://ojs.stkippgri-lubuklinggau.ac.id/index.php/SJPIF 
berbasis discovery learning pada materi keseimbangan dan dinamika rotasi dilakukan dikelas XI MIPA 3 dengan menggunakan siswa 9 orang yang terdiri dari 3 kemampuan tinggi, 3 kemampuan sedang, 3 kemampuan rendah.

Tabel 6. hasil rekapitulasi penilaian angket kepraktisan kelompok terbatas

\begin{tabular}{ccc}
\hline Kode siswa & Jumlah & Kategori \\
\hline S-1 & 30 & Baik \\
S-2 & 34 & Sangat baik \\
S-3 & 33 & Sangat baik \\
S-4 & 35 & Sangat baik \\
S-5 & 35 & Sangat baik \\
S-6 & 31 & Baik \\
S-7 & 33 & Sangat baik \\
S-8 & 35 & Sangat baik \\
S-9 & 33 & Sangat baik \\
Rata-rata & 299 & Sangat baik \\
\hline
\end{tabular}

Hasil respon siswa terhadap kepraktisan buku yang dikembangkan menyatakan bahwa modul fisika berbasis discovery learning materi keseimbangan dan dinamika rotasi dengan penilaian 299. Jadi, persentase yang dimiliki modul fisika materi keseimbangan dengan kategori sangat baik atau dengan penilaian 299. Dan hasil dari angket respon siswa yang didapat yaitu 33,2 jadi dapat disimpulkan bahwa modul fisika berbasis Discovery Learning dapat digunakan.

Dalam pembahasan pada penelitian ini memiliki tujuan penting dari penelitian yaitu menghasilkan modul fisika yang bersifat valid, dan praktis. Dimana modul adalah modul fisika berbasis discovery learning pada materi keseimbangan dan dinamika rotasi di kelas XI MIPA. Terdapat tahap desain yang kemudian dilanjutkan dengan kegiatan validasi serta uji coba produk yang dikenmvbangkan. Hasil yang diharapkan dari pengembangan ini adalah modul fisika berbasis discovery learning yang valid dan praktis.

Pendapat ini didukung oleh hasil penelitian Sawitri, et al. (2014) yang menyatakan bahwa modul pembelajaran yang berkualitas dan layak digunakan jika telah memenuhi standar kevalidan yang dinilai oleh ahli dan pakar. Selain itu Hala, et al. (2015) menyatakan validasi telah memenuhi kriteria kevalidan jika dalam hal ini instrumen yang dikembangkan telah didasari pada kajian rasional teoritik yang kuat serta memiliki konsistensi secara internal. 
Kepraktisan modul dilihat darirespon positif siswa terhadap modul pembelajaran disebabkan karena terdapat petunjuk penggunaan modul pembelajaran sehingga mereka mampu melakukan pembelajaran secara mandiri, siswa memahami langkah kerja yang terdapat dalam lembar kegiatan siswa karena didukung oleh bahasa dan petunjuk yang mampu menuntun mereka untuk melakukan kegiatan, terdapat gambar atau ilustrasi yang dapat diamati untuk memudahkan siswa dalam memahami pelajaran, terdapat informasi pendukung yang dapat menambah pengetahuan mereka, dan terdapat soal-soal latihan untuk meningkatkan pengetahuan dan soal-soal untuk melakukan asesmen secara mandiri (Setiyadi, M. W, 2017).

Desain pengembangan yang digunakan dalam penelitian ini menggunakan model pengembangan Four-D. Dimana model ini terdapat 4 langkah yaitu tahap define, tahap design, tahap develop, dan tahap disseminate. Namun peneliti hanya menggunakan sampai tahap develop saja. Modul ini awalnya di desaign seperti kelayakan bahan ajar pada umumnya terkhusus modul yang sudah banyak terbit. Namun pada tampilan cover modul harus menyatu antara tulisan dari warna dasar cover sehingga tidak diperlukan lagi adanya penulisan didalam box atau tempat-tempat tertentu.

Menurut supriyono (2015) buku teks atau bahan ajar merupakan media pembelajaran yang sangat membantu siswa dalam mempelajari materi pelajaran dan telah dimanfaatkan berulang-ulang dalam proses pembelajaran. Buku yang dimaksud disini adalah buku pelajaran dimana buku pelajaran seringkali ditemui disekolah yang digunakan sebagai sumber belajar siswa. Namun buku ajar memiliki keunggulan dan kelemahan pada setiap produksinya. (dalam supriyono 2015) keunggulan pada bahan ajar bisa membuat siswa belajar secara mandiri, buku juga mudah untuk dibawa kemana-mana, buku juga berisi tentang ilmu pengetahuan maupun perkembangan ilmu yang lebih luas, serta buku dapat meningkatkan pemahaman dan penalaran sehingga para pembaca dapat memikirkan dan meninjau dengan cara yang tidak mungkin dilakukan dengan program yang terikat waktu.

Adapun kelemahannya (dalam supriyono , 2015:87) tidak mampu mempresentasikan gerakan, pemaparan materi bersifat linier, tidak mampu mempresentasikan kejadian secara berurutan, sulit memberikan pemahaman pada bagian-bagian tertentu apabila pembaca sulit untuk memahami makna dari buku yang dikembangkan, sulit memberikan umpan balik untuk pertanyaan yang diajukan yang memiliki banyak kemungkinan jawaban atau pertanyaan yang membutuhkan jawaban yang kompleks dan mendalam, tidak dapat mengakomodasi siswa dengan keampuan baca terbatas karena buku cetak dibuat pada tingkat baca tertentu. 
Modul tidak hanya berisi tentang materi saja namun modul juga harus memiliki model pembelajaran didalamnya. Salah satu model pembelajaran yang digunakan yaitu model berbasis Discovery Learning. (Dalam Asmarani, 2016 ) yakni proses pembelajaran yang terfokus pada penemuan masalah yang berasal dari pengalaman nyata siswa. Model discovery learning diharapkan dapat mempengaruhi sikap positif atau sikap ilmiah siswa yang diperlukan sehingga dapat meningkatkan kemampuan siswa demi tercapainya tujuan pembelajaran (Ahsmarani, 2016).

\section{SIMPULAN}

Berdasarkan penelitian yang telah dilakukan, peneliti menyimpulkan bahwa:

1. Peneliti melakukan proses pengembangan modul fiska berbasis discovery learning pada materi keseimbangan dan dinamika rotasi. penelitian ini menggunakan model pengembangan Four-D melalui 4 tahapan mulai dari define, design. Develop, disseminate

2. Hasil kelayalakan terhadap modul fisika berbasis discovery learning secara keseluruhan yaitu 82 sehingga bisa dikatakan modul fisika berbasis discovery learning valid. Penilaian untuk angket respon siswa pada modul fisika berbasis discovery learning mencapai penilaian 83,05 bisa dikatakan sangat setuju atau praktis untu digunakan .

\section{DAFTAR PUSTAKA}

Apriyani, N., Ariani, T., \& Arini, W. (2020). Pengembangan Modul Fisika Berbasis Discovery Learning pada Materi Fluida Statis Siswa Kelas XI SMA Negeri 1 Lubuklinggau Tahun Pelajaran 2019/2020. Silampari Jurnal Pendidikan Ilmu Fisika, 2(1), 41-54.

Ariani, T., \& Suanti, W. (2016). Efektivitas Penggunaan Model Pembelajaran Problem Based Learning (PBL) Pada Pembelajaran Fisika Siswa Kelas VIII SMP Negeri 2 Lubuklinggau Tahun Pelajaran 2015/2016. Jurnal Inovasi dan Pembelajaran Fisika, 3(2).

Asmarani 2016. Peningkatan Sikap Ilmiah Siswa Melalui Penerapan Model Discovery Learning. Jurnal Pendidikan Dan Pembelajaran Biologi, 1(1) 16-22.

Daryanto. 2014. Pendekatan Pembelajaran Scientific Kurikulum 2013. Yogyakarta:Gava Media.

Hala, Y., Saenab, S., Kasim. S. (2015). Pengembangan Perangkat Pembelajaran Biologi Berbasis Pendekatan Saintifik Pada Konsep Ekosistem Bagi Siswa Sekolah Menengah Pertama. Journal of Educational Science and Tecnology, Volume 1 Nomor 3: 85-96.

Miswati, M., Amin, A., \& Lovisia, E. (2020). Pengembangan Media Pembelajaran Power Point Macro Berbasis Problem Based Learning Materi Besaran dan Pengukuran 
Sebagai Sumber Belajar Siswa Kelas X. Silampari Jurnal Pendidikan Ilmu Fisika, 2(2), 77-91.

Peniati, E. (2012). Pengembangan modul mata kuliah strategi belajar mengajar IPA berbasis hasil penelitian pembelajaran. Jurnal Pendidikan IPA Indonesia, 1(1).

Sawitri, D. W., Ambarwati, R., \& Wisanti. (2014). Pengembangan Modul Keanekaragaman Hayati Berbasis Pendekatan Saintifik Untuk Siswa Kelas X Sma. BioEdu Berkala Ilmiah Pendidikan Biologi, Vol.3 No.3.

Setiyadi, M. W. (2017). Pengembangan modul pembelajaran biologi berbasis pendekatan saintifik untuk meningkatkan hasil belajar siswa. Journal of Educational Science and Technology (EST), 3(2), 102-112.

Sugiyono. (2012). Metode Penelitian Pendidikan (Pendekatan Kuantitatif, Kualitatif dan R\&D). Bandung: Alfabeta.

Supriyono 2015. Pengaruh Buku Teks Dan Cetak Terhadap Hasil Belajar Di SMA N 1 Marga Tiga Kabupaten Lampung Timur Pada Kelas XII. Jurnal Pendidikan Ekonomi 3(1) 8292.

Trianto. 2011. Model Pembelajaran Terpadu : Konsep, Strategi, Dan Implementasinya Dalam Kurikulum Tingkat Satuan Pendidikan (KTSP). Jakarta: Bumi Aksara. 